\title{
REPRESENTAMEN CINTA DALAM KISAH NABI SULAIMAN DAN RATU SABA' SURAT AN-NAML (Studi Analisis Semiotika dan Komunikasi Interpersonal)
}

\author{
Muhamad Agus Mushodiq \\ Institut Agama Islam Ma'arif NU (IAIM NU) Metro Lampung \\ agusmushodiq92@gmail.com
}

\begin{abstract}
This paper aims to find the meanings of the signs which are contained in the Prophet Sulaiman and Saba' Queen story. On the other view, this paper aims to reveal the interpersonal communication process between them that allegedly contain expression of love which ended in marriage. These meanings are analyzed using Peircean semiotics. Peircean semiotics focus of its triadic system, with the result that researcher has to pass three stages of analysis (represntament, object and interpretant) when he interpret the signs, and also this research intended to apply the interpersonal communication theory. After reading Prophet Sulaiman and Saba' Queen story through Peircean semiotic views and interpersonal communication theory, this research finds some language symbols which are indicated love expressing. Those language symbols -among others- are the application of fil mabni li majhul qila that implicated meaning of Sulaiman's hospitable and friendly attitude to Queen Saba'. Direct imperative sentence without harfu nida ya' implicate Sulaiman's hope to feel close with Saba' Queen. And then, love indication that shown by Saba' Queen is her positive response to Sulaiman's letter. As for the Sulaiman's feeling expression process that explained by al-Quran explicitly are (1) sensing (2) interpreting, (3) feeling, (4) intending, and (5) expressing. Whereas Saba' Queen's feeling expression process explained by al-Quran explicitly are (1) sensing and (2) expressing.
\end{abstract}

Keywords: Representament; object; interpersonal communication; sign.

\begin{abstract}
Abstrak
Tulisan ini bertujuan untuk menemukan makna dari tanda-tanda yang terdapat pada kisah Nabi Sulaiman dan Ratu saba'. Selain itu, tulisan ini juga bertujuan untuk mengungkap proses komunikasi interpersonal antar keduanya yang disinyalir menuju pada pengungkapan perasaan cinta yang berakhir pada pernikahan. Makna-makna tersebut dianalisis dengan menggunakan teori semiotika Charles sanders Pirce. Teori semiotika peirce fokus pada system triadiknya, sehingga ketika peneliti melakukan interpretasi, maka ia harus melewati tiga tahapan, representamen, objek, dan interpretan. Selain menngunakan teori semiotika, peneliti juga menggunakan teori komunikasi interpersonal guna menyingkap proses pengungkapan perasaan antara kedua tokoh. Setelah peneliti melakukan analisis dengan dua teori tersebut, ditemukan beberapa simbol kebahasaan yang merujuk pada indikasi cinta, di antaranya adalah penggunaan fi'il mabni li majhul qi>la guna memberikan kesan keramahtamahan Nabi Sulaiman terhadap Ratu Saba. Kata perintah langsung tanpa adanya harfu nida ya juga disinyalir menggambarkan keinginan Nabi Sulaiman untuk merasa dekat dengan Ratu Saba'. Adapun indikasi cinta yang ada pada diri Ratu Saba' telah nampak pada awal-awal episode kisah, di mana ia memeberikan respon positif terhadap surat yang dikirim oleh Nabi Sulaman. Adapun proses pengungkapan perasaan yang diterangkan al-Quran secara eksplisit pada diri Sulaiman adalah (1) pengamatan (sensing) terhadap Ratu Saba', (2) menafsirkan (interpreting) respon Ratu Saba', (3) mengalami perasaan tertentu (feeling) yang diakibatkan penafsiran sebelumnya, (4) menanggapi (intending) perasaan tersebut, dan (5) mengungkapkan perasaan (expressing). Adapun proses pengungkapan perasaan yang diterangkan al-Quran secara eksplisit pada diri Ratu Saba' adalah (1) pengamatan (sensing) terhadap Nabi Sulaiman dan (2) pengungkapan (expressing) perasaan.
\end{abstract}

Kata kunci: Representamen; objek; komunikasi interpersonal; tanda 



\section{A. PENDAHULUAN}

Supraktiknya (1995: 50) meyakini bahwa salah satu hal yang membahagiakan di dalam komunikasi interpersonal adalah pengungkapan perasaan. Saling mengungkapkan perasaan akan menimbulkan ikatan kuat antara dua orang yang berkomunikasi. Bahkan ia meyakini bahwa saling mengungkapkan perasaan akan berakibat baik pada kesehatan psikologi (Supraktiknya, 1995: 50). Perasaan merupakan hal abstrak yang ada pada diri manusia. Sehingga untuk menampakkannya, seseorang perlu bentuk konkrit yang di dalam kajian semiotika disebut dengan sinsign pada ranah representamen.

Berbagai macam perasaan melekat pada diri manusia secara umum. Rasa bahagia, sedih, benci, cinta, amarah dan masih banyak lainnya merupakan hal yang lumrah muncul di dalam kehidupan mereka. Dalam mengungkapkan perasaan tersebut, manusia juga memiliki banyak sekali bentuk. Rasa cinta misalnya, banyak sekali bentuk sinsign dari rasa cinta. Di kalangan masyarakat luas -baik masyarakat Indonesia maupun masyarakat luar- mawar merah merupakan sinsign dari rasa cinta. Hal tersebut terbukti dengan banyaknya mawar merah yang terjual pada hari valentine yang disinyalir sebagai hari kasih sayang dan cinta. Begitu juga dengan coklat, coklat yang disinergikan dengan mawar merah akan menjadi satu kesatuan utuh dan sempurna yang digunakan dalam mengungkapkan perasaan cinta. Lain halnya dengan Niza>r Qubbani, ia memilih "diam" sebagai bentuk dari rasa cinta. Hal tersebut nampak pada syairnya yang berbunyi:

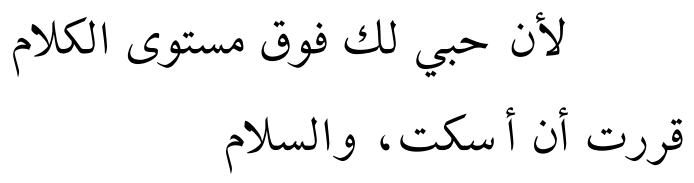

Oleh karena cintaku padamu lebih dari sekedar ucapan, maka aku memutuskan untuk diam, wassalam

Selain dua bentuk ungkapan cinta tersebut, peneliti meyakini bahwa masih banyak lagi bentuk-bentuk lain dari ungkapan cinta. Untuk itu dalam kajian ini, peneliti akan mencoba membongkar bentuk cinta yang ditampilkan oleh al-Quran, khususnya dalam kisah Nabi Sulaiman as dan Ratu Saba'.

Di dalam perjalanan hidupnya, Nabi Sulaiman memiliki episode kisah yang unik bersama seorang ratu di negeri Saba'. Sebagian ulama berpendapat bahwa ratu tersebut bernama Bilqis. Di dalam Surat anNaml, Allah menceritakan kisah Nabi Sulaiman dan Ratu Saba' dengan disertai komunikasi interpersonal antara keduanya. Interaksi keduanya mengundang perdebatan di kalangan para ulama mengenai pernikahan antara keduanya. Mengingat bahwa di dalam al-Quran tidak ditampilkan secara detail mengenai pernikahan tersebut. Menurut ar-Razi dan as-Suyuti (2012: 268), Nabi Sulaiman dan Ratu Saba' menikah berdasarkan indikator yang ada pada ayat "wa aslamtu ma'a Sulaiman lillahi rabbi al-'alamin." Adapun Muhammad ibn Isha>q sangat patuh dengan apa yang ditampilkan al-Quran secara eksplisit bahwa tidak diterangkan secara detail mengenai pernikahan keduanya. Sehingga ia menganggap bahwa keduanya tidak menikah.

Berdasarkan dua pendapat kontradiktif tersebut, peneliti mencoba mengulas interaksi interpersonal antara 
Nabi Musa dan Ratu Saba' untuk mengetahui kecondongan pendapat yang lebih masuk akal dan tidak apologis dengan menggunakan kaca mata semiotika dan komunikasi interpersonal. Secara kasat mata, peneliti melihat adanya indikasiindikasi cinta antara keduanya. Indikasi tersebut terlihat pada interkasi yang intensif antara Nabi Sulaiman dan Ratu Saba' di ayat-ayat terakhir yang menceritakan keduanya. Mengingat bahwa pada awalawal ayat, Nabi Sulaiman menggunakan dhamir hum yang merujuk pada Ratu Saba' dan kaumnya, dan tidak terlihat keintensifan komunikasi antara keduanya. Proses perubahan intensifitas interaksi tersebut disinyalir sangat berkaitan erat dengan proses pengungkapan perasaan yang dikemukakan Johnson yang akan ditampilkan peneliti pada landasan teori. Di sisi lain kajian semiotika akan membantu peneliti menangkap makna dari tandatanda yang ditampilkan al-Quran di dalam Kisah Nabi Sulaiman dan Ratu Saba' baik berupa tanda verbal (tanda bahasa) maupun tanda-tanda lain yang bersifat non verbal ( khususnya psikologis).

Untuk itu, di dalam penelitian ini peneliti menggunakan dua pisau bedah. Yaitu semiotika sebagai pembedah makna dari tanda-tanda verbal maupun non verbal yang ditampilkan al-Quran dan komunikasi interpersonal yang akan mengupas proses interaksi interpersonal antara individuindividu yang dijadikan objek material pada penelitian ini. Perlu diketahui juga bahwa dalam menginterpretasikan tandatanda tersebut, peneliti dibantu dengan beberapa buku tafsir al-Quran. Lebih rinci lagi, objek penelitian yang dijadikan objek material pada penelitian ini adalah Surat an-Naml ayat ke- 28 hingga ayat ke- 44 . Penelitian ini diproyeksikan menjawab dua rumusan masalah yaitu, (1) bagaimanakah proses tahapan pengungkapan perasaan cinta yang ditampilkan al-Quran di dalam kisah Nabi Sulaiman dan Ratu Saba'?, (2) apa representamen cinta yang ditampilkan Nabi Sulaiman dan Ratu Saba'?

\section{B. SEKILAS TENTANG SEMIOTIKA DAN KOMUNIKASI INTERPERSONAL}

\section{Teori Semiotika Charles S. Peirce}

Klasifikasi dan analisis makna sebuah tanda yang didasarkan pada teori semiotika yang dicetuskan oleh Peirce, tidak mungkin terlepas dari unsur triadik yang ia kemukakan (Danesi, 2012: 32). Ketiga unsur tersebut ialah representament, object, dan interpretant.

Dari segi representament, atau selanjutnya juga akan disebut dengan ground, akan dijumpai tiga jenis tanda. Adapun ketiganya adalah qualisign yang menempati hierarki pertama (firstness), sinsign yang menempati hierarki kedua (secondness), dan legisign yang menempati hierarki ketiga (thirdness).

Tanda qualisign memiliki pengertian dasar sebagai tanda yang didasarkan pada suatu sifat (Aart Van Zoest, 1993: 66) dan perasaan indra yang masih abstrak (Said Bankarad, 2005: 110). Adapun tanda sinsign merupakan pewujudan qualisign sebagai tanda pada bidang yang mungkin. Dalam teks sastra tanda sinsign dapat dicari dengan membandingkan teks sastra yang dikaji dengan teks sastra lainnya. Dengan perbandingan tersebut akan ditemukan ciri khas bentuk tanda sinsign antara teks sastra yang dikaji dengan teks sastra lainnya (Aart Van Zoest, 1993: 66). Penalarannya adalah dengan penghayatan estetis dan keterharuan khusus. Adapun pengertian dasar legisign adalah tanda yang merupakan tanda atas suatu peraturan 


\section{REPRESENTAMEN CINTA DALAM KISAH NABI SULAIMAN \\ DAN RATU SABA' SURAT AN-NAML \\ (Studi Analisis Semiotika dan Komunikasi Interpersonal)}

yang berlaku umum, konvensi, dan kode. Konvensi tersebut terikat dengan tanda bahasa yang membangun teks, maupun budaya spesifik yang melatar belakangi teks cerita. Perlu diketahui bahwa tanda-tanda menjadi legisign sepenuhnya sesuai dengan keinginan peneliti. Penelitilah yang menentukan kode menjadi kesepakatan yang dipakai untuk mengartikan tanda, tentunya didasari dengan argumenargumen ilmiah (Aart Van Zoest, 1993:70).

Adapun keterkaitan tanda dengan objek yang diacunya, akan ditemukan tiga macam tanda. Ketiga macam tanda tersebut ialah ikon, indeks, dan simbol. Pengertian dasar tanda ikon adalah tanda yang memiliki persamaan dengan objek yang diacunya. Ikon berdiri pada taraf first sebagaimana qualisign. Di dalam teks sastra tanda ikonis banyak muncul di luar situasi percakapan. Di dalam sebuah kalimat yang dianggap tanda, bisa diuraikan urutan kronologi kata dalam wilayah yang didenotasikan (Aart Van Zoest, 1993:70). Jadi urutan kata maupun kalimat adalah tanda ikonis. Ikon juga bisa berwujud dalam bentuk penulisan, hal ini kebanyakan ada pada karya sastra berbentuk puisi. Ikon juga memiliki beberapa macam jenis (Said bankarad, 2005: 117), antara lain ikon tipologi (as-sūrah) yang berada pada tingkat pertama (first), ikon diagramatis (ar-rasm albayani) yang berada pada tingkat kedua (second), dan ikon metaforis (al-isti'arah) yang berada pada tingkat ketiga (third).

Tanda kedua dari segi keterkaitan tanda dengan denotatum adalah tanda indeks. Di dalam teks sastra, tanda indeksikal berperan dalam menjawab pertanyaan yang menyangkut adanya kemungkinan-kemungkinan kebenaran teks sastra dengan kenyataan/ fakta/kejadian nyata yang digambarkan dalam teks tersebut, baik dari segi psikologis, sosiologis, historis, dan lain sebagainya. Peran yang kedua menjawab pertanyaan mengenai otentik-tidaknya, jujur-tidaknya pengarang teks sastra, dan peran ketiga menjawab pertanyaan mengenai kondisi pembaca teks, apakah ia memahami dan apakah ia tersentuh dengan teks sastra tersebut (Aart Van Zoest, 1993: 79). Di dalam teks sastra, banyak kata-kata yang dirancang sebagai tanda indeksikal seperti kata di sini, di sana, atas, bawah, dia, kami, aku dan kata-kata lain yang sifatnya menunjuk (deiksis) (Danesi, 2012: 37).

Tanda terakhir dari segi keterkaitan tanda dengan denotatum adalah simbol. Pengertian dasar simbol adalah tanda yang hubungan antara tanda dan denotatumnya ditentukan oleh suatu peraturan yang berlaku umum. Simbol berada pada taraf ketiga (third). Tanda simbolis yang paling banyak ditemukan dalam teks sastra adalah tanda bahasa. Dalam teks sastra, retorika, kaidah penulisan kata, kaidah-kaidah khusus suatu bahasa, teknik penulisan kalimat, dan histori makna sebuah kata pun bisa menjadi simbol.

Klasifikasi terakhir adalah hubungan tanda dengan interpretant. Pada klasifikasi ini, akan ditemukan tiga macam tanda, yakni rheme, dicisign, dan argument. Ketiga tanda tersebut saling berkaitan antara satu dengan lainnya. Pengertian dasar rheme adalah tanda yang dapat diinterpretasikan sebagai representasi dari suatu kemungkinan denotatum. Kata-kata yang belum memiliki konteks merupakan rheme karena masih bisa ditafsirkan dengan berbagai konteks. Dalam menafsirkan teks, kita tidak mungkin melewati rheme, karena rheme merupakan firstness. Setelah rheme 
adalah tanda dicisign. Pengertian dasar dicisign adalah tanda yang bagi interpretannya tanda itu menawarkan hubungan yang benar ada di antara tanda dan denotatum. Dengan demikian, setelah suatu tanda berada pada tingkat rheme (firstness), ia harus beralih ke tingkat dicisign (secondness), sehingga tanda-tanda tersebut mendapatkan konteks dan akhirnya memiliki arti. Untuk mengangkat rheme menuju dicisign -dari tingkat kemungkinan (kabur) menjadi kenyataan (jelas)-dibutuhkan kamus, gramatika (qawaid allughah), dan konteks yang mengitari katakata yang dianggap sebagai tanda. Adapun tingkat yang ketiga adalah argument yang berada pada posisi thirdness. Pengertian dasar dari argument adalah tanda yang bagi interpretannya merupakan tanda yang berlaku umum. Di dalam sastra mengaitkan antara satu kalimat yang telah memiliki konteks (dicisign) dengan kalimat (dicisign) lainnya akan menjadi sebuah argument. Di dalam teks sastra, argument akan muncul beberapa kali, sehingga mengaitkan argument satu dengan argument-argument lain akan menghasilkan makna yang menyeluruh. Makna umum yang dihasilkan dari kumpulan argument bisa disebut dengan tema. Jadi, dengan kata lain bisa dikatakan bahwa mengaitkan tematema minor pada karya sastra akan menghasilkan tema mayor di dalam teks sastra.

\section{Komunikasi Interpersonal}

Menurut Trenholm dan Jensen (dalam Suranto, 2011: 3) komunikasi interpersonal merupakan komunikasi yang dilakukan antara dua orang (komunikasi diadik) yang bersifat spontan, informal, saling menerima feedback dan partisipan komunikasi berperan fleksibel. Adapun Agus M. Hardjana menjelaskan bahwa komunikasi interpersonal merupakan interaksi tatap muka antara dua orang atau lebih di mana setiap partisipan komunikasi dapat mengirim, menerima, dan menanggapi pesan secara langsung. Adapun Deddy Mulyana berpendapat bahwa komunikasi interpersonal merupakan komunikasi antara orang-orang dengan bertatap muka yang mana setiap partisipan berhak memberikan reaksi kepada partisipan lainnya baik secara verbal maupun non verbal. Menurut Johnson (dalam Supraktiknya, 1995: 9) komunikasi interpersonal sangat penting dilakukan karena beberapa hal, (1) komunikasi interpersonal dapat membantu mengembangkan intelektual dan sosial seseorang, (2) identitas seseorang akan terbentuk ketika ia berinteraksi dengan orang lain, (3) dengan adanya komunikasi interpersonal akan memunculkan perbandingan antara pengalamanpengalaman partisipan sehingga dapat menghadapi realitas di dunia dengan bijak, dan (4) komunikasi interpersonal akan sangat berefek baik terhadap kesehatan mental seseorang.

Dengan memperhatikan definisi di atas, dapat dipahami bahwa komunikasi interpersonal merupakan kegiatan yang mengandung konsep barter. Barter yang dimaksud adalah barter tentang pendapat dan khususnya saling berbagi perasaan. Dalam mengungkapkan perasaan ada lima tahapan yang dialami seseorang sebagaimana yang dijelaskan oleh Johnson (dalam Supraktiknya, 1995: 50). Pertama, seseorang akan mengamati (sensing) tingkah laku lawan komunikasi baik verbal maupun non verbal. Seseorang akan mengamati apa saja yang dikatakan oleh lawan komunikasinya, nada suaranya, sorot matanya, raut mukanya dan lain sebagainya. Kedua, seseorang akan menafsirkan (interpreting) semua informasi 
(Studi Analisis Semiotika dan Komunikasi Interpersonal)

yang ia dapat dari lawan komunikasinya. Cara untuk menafsirkan informasi ditentukan oleh tiga faktor utama, yaitu (1) informasi itu sendiri, (2) dugaan (hipotesis) tentang hal-hal yang menyebabkan atau melatarbelakangi tingkah laku lawan komunikasi, (3) sudut pandang penerima informasi. Ketiga, seseorang akan mengalami perasaan tertentu (feeling) sebagai reaksi spontan terhadap penafsiran yang dilakukan atas informasi yang didapat dari lawan komunikasi. Keempat, seseorang akan terdorong untuk menanggapi (intending) perasaan tersebut. Menurut Johnson, di dalam seseorang terdapat intense yang akan mendorong dan mengarahkan seseorang untuk melakukan suatu hal sesuai dengan perasaan seseorang tersebut. Kelima, mengungkapkan (expressing) perasaan. Di dalam penelitian ini, peneliti berusaha mendeskripsikan dan menganalisis interaksi interpersonal yang dilakukan oleh tokoh-tokoh kisah yang telah ditentukan di dalam al-Quran dengan mengaitkannya dengan lima tahapan pengungkapan perasaan yang dipaparkan oleh Johnson di atas.

\section{PEMBAHASAN}

Kisah Nabi Sulaiman dan Ratu Saba' di dalam al-Quran khususnya yang terdapat di dalam Surat an-Naml terangkai di dalam beberapa episode. Adapun episode kisah yang akan dibahas pada penelitian ini disesuaikan dengan pisau analisis yang digunakan, yakni komunikasi interpersonal. Sehingga penelitian kisah Nabi Sulaiman dan Ratu Saba' dimulai sejak Nabi Sulaiman mengirimkan "surat suci" untuk Ratu Saba dan para pengikutnya sebagai ajakan untuk tunduk pada konsep Islam pada saat itu. Di sisi lain peneliti tidak mengesampingkan episode kisah sebelumnya sebagai alat identifikasi konteks yang berlaku pada kisah tersebut.

1. Pengiriman "surat suci"; awal komunikasi

Pengiriman "surat suci" yang dimaksud dikisahkan pada ayat ke- 28 dari Surat an-Naml, Allah berfirman:

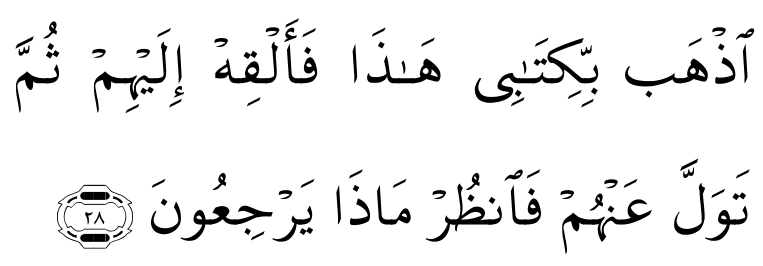

Ayat di atas menerangkan perintah Nabi Sulaiman terhadap burung Hud-hud untuk mengirimkan surat suci kepada Ratu Saba dan para pengikutnya. Pada ayat sebelumnya diterangkan bahwa Burung Hud-hud melihat sekelompok manusia yang menyembah matahari. Kelompok tersebut dipimpin oleh seorang ratu. Sehingga ia pun menceritakan fenomena tersebut kepada Nabi Sulaiman. Pada akhirnya Nabi Sulaiman memerintahkan burung Hud-hud untuk mengirimkan surat suci kepada mereaka. Pada taraf representamen, ayat di atas menggambarkan keinginan abstrak Nabi Sulaiman untuk mengamati lawan komunikasinya sebagai tanda qualisign. Keinginan abstrak tersebut diwujudkan dengan perintah yang ditugaskan kepada burung Hud-hud sebagaimana yang terdapat pada ayat di atas. Untuk menuju pemahaman atas keinginan abstrak tersebut, ditampilkan di sini analisis pada taraf objek yang dikaitkan dengan simbol dan indeks. Deiksis haz|a yang ada pada bikitabi haz|a mengandung makna tauki>d. Hal tersebut mengindikasikan bahwa surat tersebut merupakan suatu hal yang sangat 
penting untuk disampaikan kepada Ratu Saba'. Pada ayat di atas pengiriman surat suci digambarkan dengan idiom alqa ila (ألقى) (إلى) yang terdapat pada kalimat fa alqihi ilaihim. Di dalam Lisan al-Arab, alqa bermakna t\}arahła yang bermakna melempar dan menyampaikan sesuatu yang berorientasi pada suatu akibat. Artinya bahwa pengirian surat yang dilakukan Nabi Sulaiman mengandung suatu akibat dan respon yang diharapkan muncul dari pihak yang diberi surat. Kandungan makna tersebut dikuatkan dengan kalimat setelahnya yang menunjukkan bahwa Sulaiman memang menghendaki suatu respon dari ratu Saba dan kaumnya, s|umma tawalla anhum fanz\}ur $m a z \mid a$ yarjiu> $n$. Kata sambung (adawatu arrabti) yang digunakan pada ayat tersebut ialah s|umma dan fa. Menurut Musthafa Gula>yain (1993: 245) kata sambung s|umma memiliki makna li at-tartib dan at-tarakhi. Hal tersebut menunjukkan bahwa ada jeda waktu yang relatif lama untuk melihat respon spontan dari Ratu Saba'. Setelah memerintahkan Hud-hud berpaling, Nabi Sulaiman memerintahkannya untuk mengamatinya dengan harfun at jaf fa yang menunjukkan makna langsung tanpa jeda waktu. Adapun kata yarjiu $>n$ yang berasal dari kata raja'a dijelaskan Ibn A'rabi -dalam menafsirkan ungkapan Rajiz- merupakan respon dari perkataan atau perbuatan lawan bicara. Adapun jika merujuk pada penjelasan yang diungkapkan oleh Quhaif, maka kata raja'a merujuk pada respon yang mengandung konsep "akibat yang baik"(Ibnu Manzur, tanpa tahun: 116).

Pada ayat tersebut juga terdapat empat kata kerja amr dalam satu ayat. Empat perintah yang digambarkan alQuran menunjukkan keijazan al-Quran da;lam menyampaikan pesan sekaligus disinyalir menggambarkan otoritas dan kedudukan Sulaiman di hadapan para pengikutnya.

Pada ranah komunikasi interpersonal, apa yang dilakukan oleh Nabi Sulaiman merupakan proses pengamatan (sensing) terhadap lawan komunikasi. Pada awal episode kisah di atas yang menjadi lawan komunikasi Nabi Sulaiman adalah Ratu Saba' dan para pengikutnya. Hal tersebut terbukti dengan indeks kata ganti hum yang terdapat pada syibhu al-jumlah "ilaihim". Pengamatan yang dilakukan Sulaiman sangat nampak pada kalimat fanz\}ur maz|a yarjiu $>n$. Kata naz|ara di dalam Lisa $>n$ alArab memiliki makna berupa taammulu assyai'i bi al-'ain yang bermakna mengamati sesuatu dengan mata (Ibnu Manz \}ur, tanpa tahun: 215). Dengan demikian sangat jelas bahwa pada ayat tersebut Sulaiman ingin mengamati Ratu Saba' dengan perantara burung Hud-hud. Artinya bahwa awal dari proses pengungkapan perasaan sudah dilakukan Sulaiman ketika mengirimkan surat. Namun perlu diketahui juga bahwa apa yang dilakukan Sulaiman dalam mengamati Ratu Saba' juga demi lancarnya proyek besar setiap rasul yaitu menyeru manusia untuk menyembah Allah.

2. Ratu Saba' menerima surat dan respon terhadapnya
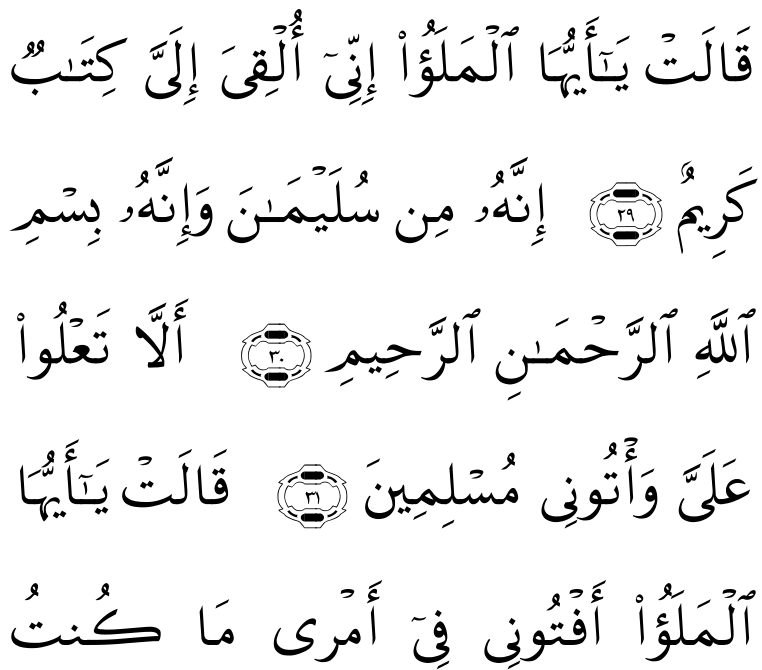


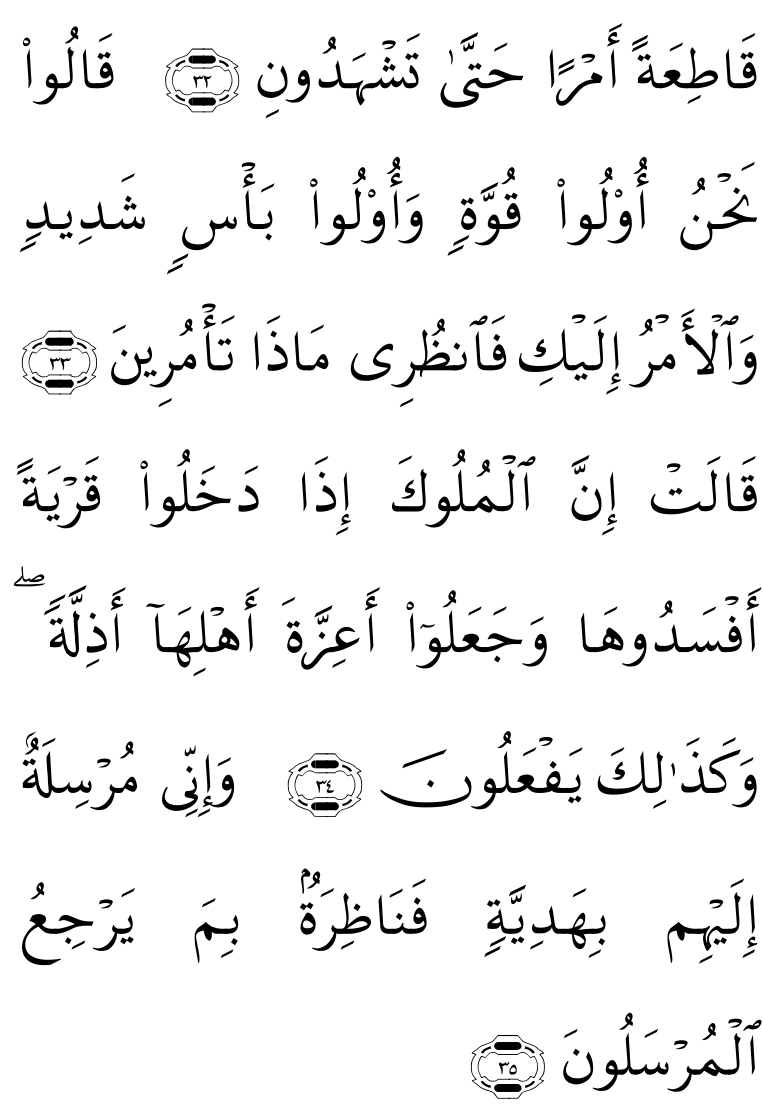

Pada ayat ke 29 sangat jelas menggambarkan respon baik Ratu Saba' terhadap surat suci yang dikirimkan Sulaiman. Respon baik tersebut merupakan qualisign yang diwujudkan melalui ungkapannya yaitu inni ulqiya ilayya kita>bun kari>mun sebagai sinsign. Pada ungkapannya tersebut terdapat deviasi antara isi surat dan apa yang ia katakan kepada para penganutnya. Ungkapan ulqiya ilayya merujuk pada pengiriman surat yang seakan-akan hanya ditunjukkan kepada dirinya saja. Artinya bahwa Ratu Saba' merasa bahwa surat tersebut dikirimkan khusus untuknya. Hal tersebut sangat kontras dengan isi surat suci yang dikirimkan Sulaiman. Nabi Sulaiman menggunakan z|amir antum pada suratnya tersebut sebagaimana yang terlihat pada kalimat alla ta'lu alayya wa'tu>ni muslimi >n. Sehingga sasaran surat tersebut adalah Ratu
Saba' dan seluruh penganutnya. Dengan demikian dapat dipahami bahwa seharusnya, Ratu Saba mengatakan "ulqiya ilaina" jika dikaitkan dan disesuaikan dengan isi surat tersebut. Tanda lain yang menunjukkan respon baik Ratu Saba' terhadap surat tersebut adalah ungkapannya yang berupa "kita>bun kari>mun". Bagaimana mungkin seseorang yang memiliki paham berbeda langsung memuji paham seseorang yang berbeda dengannya. Hal tersebut tidak mungkin dilakukan tanpa adanya kekaguman yang ada pada diri Ratu Saba terhadap Nabi Sulaiman. Di dalam kata mutiara Arab terdapat suatu ungkapan bahwa "wa ainu ar-rida 'an kulli 'aibin kalilatun wa 'ainu assukhti tubdilu masawiya".

Menurut Abd al-Karim Zaydan (2009: 296) faktor yang membuat Ratu Saba' memuji surat suci tersebut ialah cara surat tersebut sampai pada dirinya dan pengirim surat tersebut. Hanya raja yang memiliki kelebihan khusus yang dapat mengirimkan surat pada saat itu dengan menggunakan perantara burung yang berakal dengan mengirimkan surat lalu berpaling seakan akan ingin mengawasinya. Di samping itu menurut Zaydan pamor dan reputasi Sulaiman sebagai raja dan nabi sanagat menonjol dan populer, sehingga Ratu Saba' merasa tersanjung telah dikirim surat oleh raja yang terkenal pada saat itu. Kepopuleran Nabi Sulaiman terbukti dengan ungkapan Ratu Saba' "innahu min sulaiman" yang di dalamnya terkandung konsep taukid. Padahal isi surat tersebut dimulai dengan bismillahirrahmanirrahim tanpa diawali dengan nama pengirim surat -yang dimaksud di sisni adalah Nabi Suliaman- terlebih dahulu (Zaydan, 2009: 293). Artinya bahwa ungkapan innahu min sulaiman merupakan ungkapan spontan 
yang tercipta dari sinergi antara kekaguman Ratu Saba' terhadap Sulaiman dan kepopuleran Sulaiman sebagai raja dan nabi pada saat itu. Setelah mengatakan bahwa surat tersebut berasal dari Sulaiman ia pun membacakan isi surat tersebut kepada para pengikutnya dan meminta pendapat kepada mereka mengenai surat tersebut.

Di dalam surat yang dikirim oleh Sulaiman, Allah menggunakan diksi ata >ya'ti dalam menggambarkan perintah Sulaiaman kepada Ratu Saba dan para pengikutnya. Menurut Ibnu Mandzur (tanpa tahun: 13), salah satu makna dari kata dasar ata>-ya'ti adalah husnu mutawwaah wa al-muwafaqah (kerelaan hati dan persetujuan yang baik). Hal tersebut menunjukkan bahwa Nabi Sulaiman sama sekali tidak mengancam Ratu Saba' dan para pengikutnya untuk menyerahkan diri kepada Sulaiman -dalam hal ini menyerahkan diri untuk mengikuti paham keagamaannya-. Namun sebaliknya, ia sangat sopan dan penuh rasa hormat dalam mengajak mereka untuk menerima paham keagamannya dengan kerelaan hati dan persetujuan tanpa adanya peperangan atau kekerasan lain terlebih dahulu.

Adapun ayat ke-32 menunjukkan kebijaksanaan Ratu Saba'. Dalam memutuskan suatu tindakan ia selalu menghadirkan para pembesar kaumnya sehingga akan terjalin komunikasi yang baik antara ratu dan pengikutnya. Kebijaksanaan tersebut merupakan makna qualisign yang masih abstrak. Perwujudan dari tanda kebijaksanaan tersebut tertuang dari ungkapannya "ma> kuntu qa>tiatan amran hatta tasyhadun". Mengingat bahwa pada kalimat sebelumnya, Ratu Saba' meminta para pembesar kaumnya sebuah fatwa perihal surat Nabi Sulaiman. Pada ayat tersebut Allah menggunakan isim $f a>i l$ "qa>tiatan" untuk menggambarkan kebikjaksanaan Ratu Saba. Menurut Basyuni abd Fatta $>$ h (2010: 184) isim di dalam al-Quran menunjukkan pada makna at-tsubut wa ad-dawam (ketetapan dan kesinambungan). Artinya bahwa Ratu Saba' selalu dan konsisten menghadirkan para pembesar kaumnya dalam memutuskan suatu perkara sehingga terdapat kesepakatan yang diterima oleh seluruh elemen kerajaan.

Pada ayat ke 33, Allah menggambarkan kekuatan militer kerajaan Ratu Saba' dengan ungkapan para pembesar kaum Saba' "nahnu u>lu> quwwatin wa $u>l u>b a$ 'sin syadidin". Adapun ayat ke 34, Allah menggambarkan sudut pandang yang konsisten dan melekat pada Ratu Saba' mengenai raja. Menurut Ratu Saba' raja adalah seseorang yang selalu membuat kerusakan ketika menaklukan suatu daerah dan menjadikan para penduduknya terhina. Makna qualisign yang masih abstrak tersebut terwujudkan melalui ungkapannya yang digambarkan al-Quran dengan kata kerja mudhari' yaf'alun. Menurut Basyuni 'Abd al-Fattah (2010: 184) fiil mud\}ari berorientasi pada pemaknaan al-istimrar wa at-tajaddud. Artinya bahwa setiap raja pasti akan konsisten dan terus menerus melakukan dua hal yang telah disebutkan di atas ketika menaklukan suatu daerah. Kebijaksanaan yang ada pada Ratu Saba' dan pandangannya mengenai raja mendorongnya untuk lebih intensif mengamati Nabi Sulaiman.

Pada ayat selanjutnya, yakni ayat ke 35, Ratu Saba' melakukan pengamatan terhadap Nabi Sulaiman dengan mengirimkan utusan yang membawa hadiah. Ayat tersebut merupakan sebuah tanda yang menggambarkan kesungguhan Ratu Saba' dalam mengamati identitas Nabi 


\section{REPRESENTAMEN CINTA DALAM KISAH NABI SULAIMAN}

DAN RATU SABA' SURAT AN-NAML

(Studi Analisis Semiotika dan Komunikasi Interpersonal)

Sulaiman sebagai tanda qualisign. Menurut Muhammad 'Abid al-Jabiri (2009: 307) hadiah yang dikirmkan Ratu Saba' untuk Nabi Sulaiman adalah sebuah ujian. Jika Nabi Sulaiman menerima hadiah tersebut, maka ia adalah seorang raja yang memiliki sifat sebagaimana yang ia pahami. Namun jika Nabi Sulaiman menolak hadiah tersebut, maka dapat disimpulkan bahwa ia adalah seorang nabi sekaligus raja. Mengingat bahwa menurut Zaydan identitas kenabian Sulaiman -disamping juga dikenal sebagai raja- sudah tersohor di sebagian besar penjuru negeri pada saat itu. Adapun bukti kesungguhan Ratu Saba dalam mengamati Nabi Sulaiman adalah diksi mursilatun pada kalimat inni mursilatun ilaihim. Al-Quran lebih memilih bentuk isim daripada fi'il dalam menggambarkan keinginan Ratu Saba' untuk mengirimkan hadiah. Sebagaimana yang telah diketahui bahwa menurut Basyuni 'Abd al-Fattah, isim di dalam alQuran berorientasi pada pemaknaan as|s|ubut wa ad-dawam. Artinya bahwa Ratu Saba' benar-benar berniat dan pasti akan mengirim hadiah untuk Nabi Sulaiman. Selain itu, al-Quran juga menggunakan isim naz\}iratun pada kalimat fanazliratun bima yarji'u mursalu>n untuk menggambarkan keinginan Ratu Saba' dalam mengamati respon Nabi Sulaiman. Hal tersebut menunjukkan kesungguhan Ratu Saba dalam mengamati Sulaiman. Pengamatan (sensing) yang dilakukan Ratu Saba' merupakan tahap pertama dalam menyampaikan suatu perasaan dalam komunikasi interpersonal sebagaimana yang dilakukan Sulaiman pada awal pembahasan di atas.

\section{Respon Sulaiman terhadap hadiah} Ratu Saba; Sulaiman sebagai representasi raja dan nabi
Repon pertama yang dilakukan Sulaiman adalah menolak hadiah dan memberi gertakan kepada Ratu Saba'. Allah berfirman:

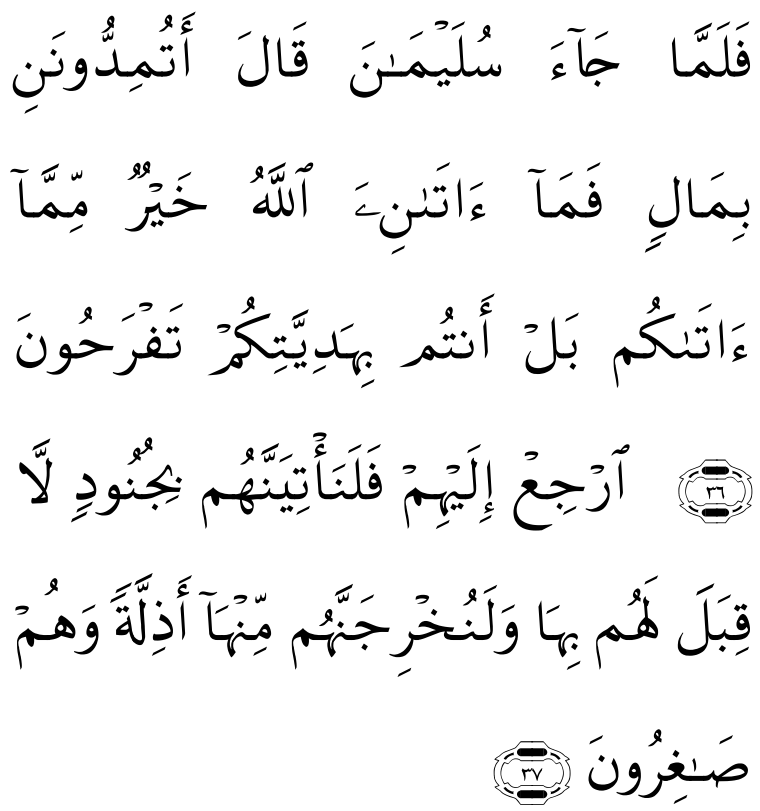

Dua ayat di atas menggambarkan identitas Nabi Sulaiman sebagai raja dan nabi pada ranah tanda qualisign. Perwujudan makna abstrak tersebut berupa dua respon yang dilakukan Nabi Sulaiman. Beliau menolak hadiah yang ditawarkan Ratu Saba dan memberi gertakan untuk menghinakan penduduk Saba'. Perlu diketahui bahwa melakukan penghinaan terhadap penduduk jajahan merupakan salah satu konsep (thought) Ratu Saba terhadap referen raja.

Penolakan hadiah yang berorientasi pada pemahaman terhadap identitas kenabian Sulaiman diindikasikan oleh ucapan Nabi Sulaiman yang meunjukkan bahwa beliau memiliki kontrak dengan Tuhan. Ungakapan yang dimaksud adalah atumiddunani bi malin fama atanillahu khairun mimma atakum. Ayat tersebut menunjukkan bahwa Nabi Sulaiman merasa anugrah yang diberikan Tuhan kepadanya jauh lebih 


\section{Jurnal al-Tsaqafa Volume 15, No. 02, Desember 2018}

baik dari pada apa yang diberikan-Nya kepada Ratu Saba'. Pada kalimat di atas terdapat kata ata>-yati yang memiliki makna berbeda dengan kata yang sama pada ayat ke 31. Adapun kata kerja ata $>$-yati pada ayat tersebut memiliki makna $\left.a^{\prime} t\right\} a$ (memberi) (Ibnu Manzur, tanpa tahun: 17). Pada ayat tersebut terlihat bahwa ikatan antara Tuhan dan nabi sangatlah erat. Mengingat bahwa Nabi Sulaiman mengaitkan segala apa yang ia miliki berasal dari Tuhan.

Meskipun demikian, dengan apa yang dilakukan Ratu Saba dalam memberikan hadiah, Nabi Sulaiman dapat menafsirkan (interpreting) identitas lawan bicaranya -dalam hal ini adalah Ratu Saba'- Dalam menafsirkan identitas Ratu Saba' Sulaiman dibantu dengan beberapa faktor. Pertama, informasi yang ia dapat dari burung Hud-hud bahwa Ratu Saba' merupakan ratu yang memilki 'arsyun adzim' singgasana yang mewah. Kedua, dugaan beliau tentang respon yang dilakukan oleh lawan bicara, dalam hal ini Ratu Saba' mengirimkan hadiah kepada Nabi Sulaiman. Ketiga, adalah sudut pandang Nabi Sulaiman terhadap apa yang ia tangkap dari fenomena-fenomena yang telah terjadi. Menurut penulis, Nabi Sulaiman sudah berhasil menafsirkan identitas Ratu Saba' bahwa ia adalah ratu yang sangat antusias dengan kemergelapan kemewahan dunia. Sehingga respon "tindakan" yang ia lakukan pada ayat ke 3841 semakin menunjukkan bahwa Nabi Sulaiman menafsirkan identitas Ratu Saba' sebagai sosok yang menyukai kemewahan dunia.

Respon kedua yang dilakukan Nabi Sulaiman adalah memberi gertakan berupa ancaman untuk menghinakan penduduk Saba' sebagai representamen bahwa ia adalah raja. Gertakan tersebut tertuang pada kalimat falana'tiyannahum bi junudin la qibala lahum biha walanukhrijannahum minha adzillah wa hum shagirun. Pada ayat tersebut nampak sekalai ancaman yang dibungkus dengan ketegasan. Al-Quran menggunakan taukid murakkab dalam menggambarkan ketegasan Nabi Sulaiman. Huruf lam attaukid yang dipadukan dengan nun taukid pada kata kerja ata>-ya'ti melahirkan kesungguhan yang luar biasa. Artinya bahwa Nabi Sulaiman -dari segi ucapannya- benar-benar akan mendatangkan prajuritnya untuk memerangi Ratu Saba' dan kaumnya. Begitu juga dengan kata kerja akhrajayukhriju yang dibubuhi dua huruf taukid lam dan nun sehingga mengorientasikan makna kesungguhan untuk mengeluarkan penduduk Saba' dari negerinya tersebut. Ancaman tersebut mengandung konsep penghinaan yang diwakili dengan kata adzillah dan peremehan yang diwakili dengan kata shagirun dalam bentuk isim fail yang berorientasi pada pemaknaan atstsubut wa ad-dawam. Dari ayat tersebut menunjukkan bahwa konsep terhadap raja yang dikemukakan oleh Ratu Saba' berlaku pada diri Nabi Sulaiman.

Namun jika dipahami dengan cermat maka akan didapati deviasi antara ucapan dan perbuatan Nabi Sulaiman. Dari segi ucapan, Sulaiman memang dapat dipandang sebagai raja. Hal tersebut terbukti dengan gertakan yang ia lakukan untuk menyembelih burung Hud-hud karena ketidakhadirannya terkecuali jika ia memberikan alasan yang jelas dan ancaman yang beliau kemukakan untuk menggertak Ratu Saba beserta para pengikutnya. Perlu diketahui juga bahwa dalam menggertak burung Hud-hud Nabi Sulaiman juga menggunakan kata kerja yang diimbuhi lam at-taukid dan nun at-taukid sebagaimana yang nampak pada kata kerja lauadibannahu 
(Studi Analisis Semiotika dan Komunikasi Interpersonal)

dan laadbahannahu. Berdasarkan hal tersebut dapat dipahami bahwa Nabi Sulaiman adalah perpaduan antara raja dan nabi. Raja dari ucapan dan ketegasannya, nabi dari sikap dan perbuatannya.

\section{Respon tindakan Nabi Sulaiman} terhadap tingkah laku Ratu Saba'; pencapaian tahap feeling

Allah berfirman:
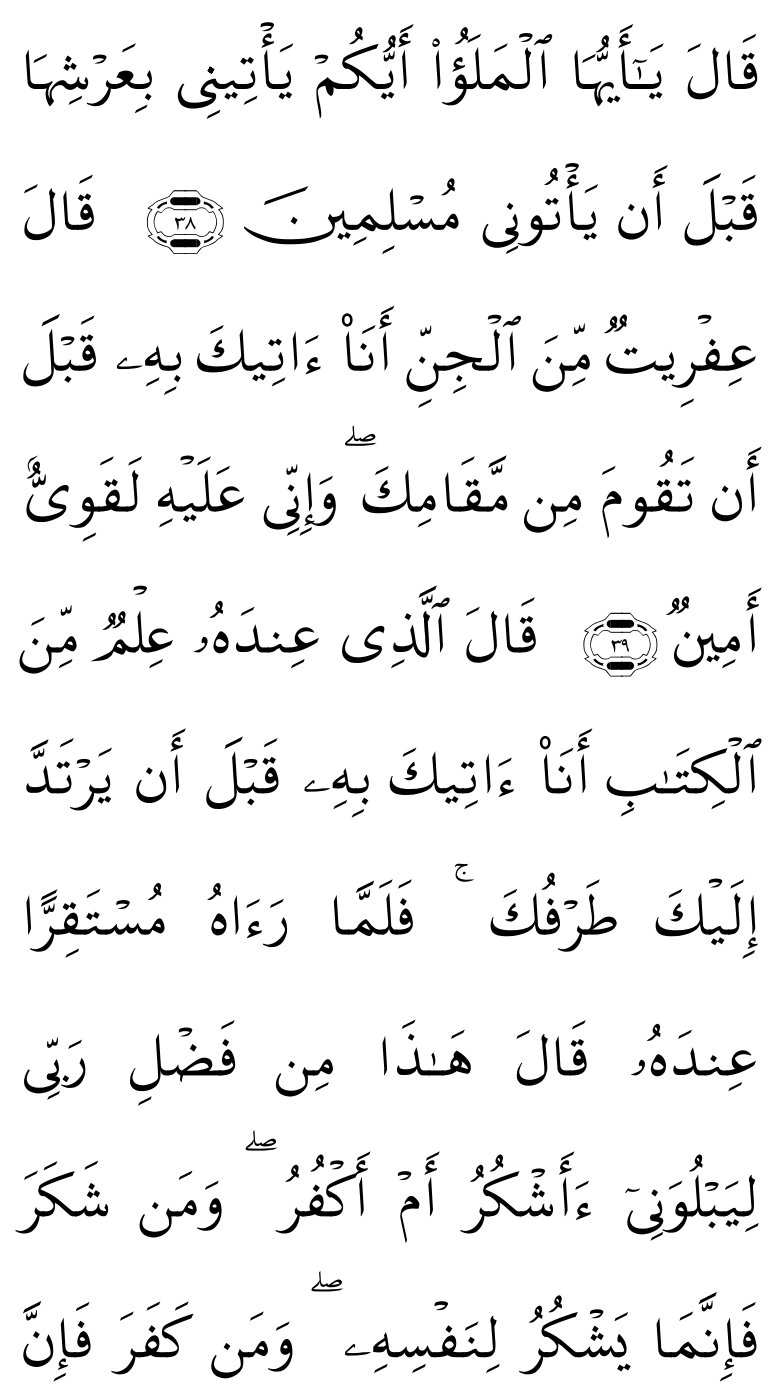

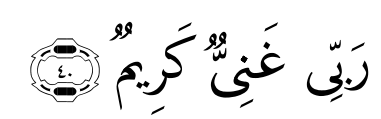

Setelah Nabi Sulaiman menolak hadiah dari Ratu Saba' dan berhasil menafsirkan identitasnya, ia mulai merasakan (feeling) tantangan (baca: tertantang) untuk menaklukan Ratu Saba'. Penaklukan yang dimaksud memiliki makna polisemi. Penaklukan dalam ranah dakwah keagamaan dan penaklukan hati. Feeling tersebut merupakan tahap ke- tiga dari lima tahapan pengungkapan perasaan. Ia juga disinyalir sebagai tanda qualisign yang diwujudkan dengan sayembara yang dilakukan Nabi Sulaiaman yang tertuang pada ayat ke-38. Pada ayat tersebut terdapat dua kata kerja yang memiliki asal yang sama namun diyakini memiliki makna yang berbeda. Kata yang dimaksud adalah ya'tini dan ya'tuni. Ya'tini pada ayat di atas diyakini merujuk pada makna saqa yang berarti membawa dan mengangkut. Adapun kata ya'tuni merujuk pada makna husnu mutawaah dan muwafaqah. Artinya Nabi Sulaiman mengadakan sayembara bagi para prajuritnya untuk dapat membawa dan mengangkut singgasana mewah Ratu Saba' dengan tujuan agar Ratu Saba' dan kaumnya datang kepada Nabi Sulaiman menyerahkan diri dengan kerelaan hati dan persetujuan utuh. Dengan demikian dapat dipahami bahwa Nabi Sulaiman menginginkan salah satu prajuritnya mengangkut singgasana Ratu Saba' dengan cara yang tidak biasa agar Ratu Saba' merasa takjub sehingga menyerahkan diri kepada Nabi Sulaiman dengan kerelaan hati.

Adapun pada dua ayat selanjutnya alQuran menggambarkan dua prajurit Nabi Sulaiman yang pamer kekuatan. Pada ayat ke-39, digambarkan di dalamnya jin yang memiliki nama Ifrit menawarkan kekuatannya untuk dapat mengangkut singgasana Ratu Saba' sebelum Nabi Sulaiman berdiri dari tempat duduknya. Ayat tersebut menggambarkan keoptimisan yang tinggi pada diri Ifrit. Al-Quran menggambarkan keoptimisannya dengan 
kalimat "ana a>tika bihi qabla an-taquma min maqamik, wa inni 'alaihi laqawiyun amin". Penggunaan isim fail atika bihi merujuka pada makna ats-tsubut wa ad-dawam. Hal tersebut menggambarkan keyakinan yang kuat pada diri Ifrit bahwa ia benar-benar mampu bahkan pasti mampu mengangkut singgasana Ratu Saba' dengan rentang waktu yang telah disebutkan sebelumnya. Konsekuensi pemaknaan isim juga berlaku bagi dua isim selanjutnya yaitu qawiyun dan aminun. Sedangkan ayat ke- 40 menggambarkan unjuk gigi yang dilakukan oleh seorang hamba yang memiliki Ilmu dari al-Kitab (alladi 'indahu ilmu min al-kitab). Pada ayat tersebut al-Quran juga menggambarkan keoptimisan yang tinggi pada diri hamba tersebut. Keoptimisan yang digambarkan sama dengan apa yang digambarkan pada pada diri ifrit. Namun hamba tersebut memilki keunggulan dalam kecepatan rentang waktu yang digambarkan dengan kalimat qabla anyartadda ilaika tarfuka (secara leksikal bemakna sebelum kembalinya tatapan matamu) sebagai kinayah yang memiliki makna kecepatan kedipan mata. Pada kalimat selanjutnya diceritakan bahwa ketika singgasana Ratu Saba' berada di depan tatapan Nabi Sulaiman ia pun berdoa sebagaimana yang tertera pada ayat tersebut.

\section{Renovasi singgasana Ratu Saba';} sebuah ujian dan tahapan penanggapan (intending)

Allah berfirman:
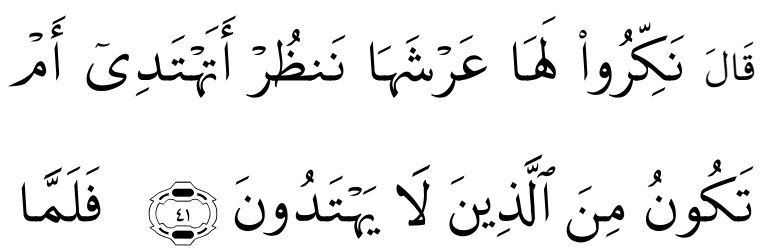
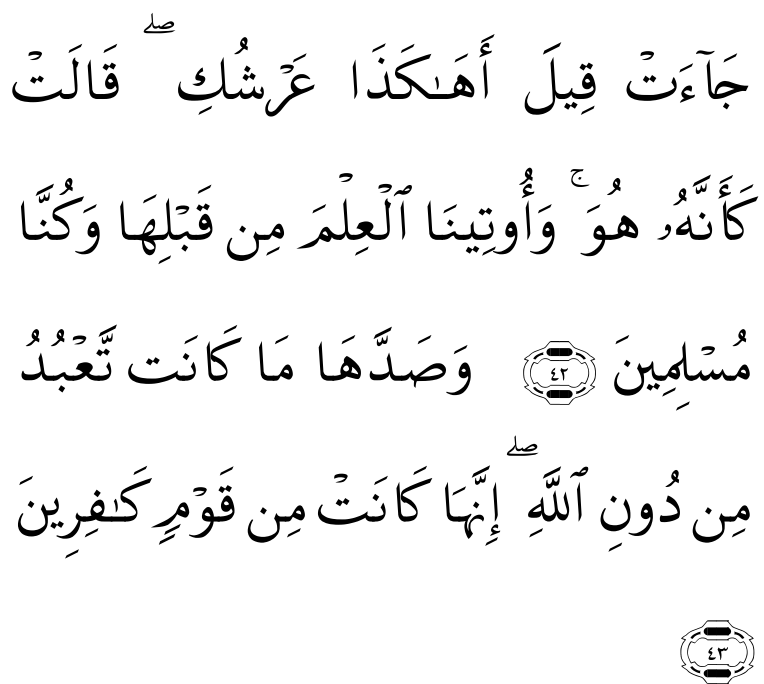

Ayat di atas menggambarkan tanggapan (intending) Nabi Sulaiman terhadap perasaan (feeling) yang telah dijelaskan sebelumnya sebagai tanda qualisign. Pengubahan yang dilakukan pada singgasana Ratu Saba' tidak sekedar pengubahan sekedarnya saja yang ditujukan untuk mengujinya apakah ia masih mengenal seinggasananya atau tidak. Namun pengubahan yang dilakukan merujuk pada renovasi yang lebih condong memperindah. Adapun bentuk dari tanda qualisign tersebut terdapat pada kata nakkiru laha 'arsyaha sebagai tanda sinsign. Ketika kata nakkiru yang berasal dari kata kerja nakkara-yunakkiru dilihat medan maknanya maka akan didapati makna berupa kecedasan, ketajaman pikiran, perubahan, dan membuat tidak diketahui. Artinya bahwa perubahan yang dilakukan Nabi Sulaiman merujuk pada aktivitas renovasi yang bertujuan untuk memperindah singgasana.

Pengubahan (baca: renovasi) yang dimaksud tidak merujuk pada pengubahan total dengan dibuktikan ayat selanjutnya (ayat ke 42) yang berbunyi ahakadza 'Arsyuki. Menurut Imam Jalalain (2012: 268) jika memang Sulaiman merenovasi seluruh singgasana Ratu Saba' maka pertanyaan yang muncul adalah a haza 'arsyuki dan 


\section{REPRESENTAMEN CINTA DALAM KISAH NABI SULAIMAN}

DAN RATU SABA' SURAT AN-NAML

(Studi Analisis Semiotika dan Komunikasi Interpersonal)

bukan a hakaza 'arsyuki. Pada ayat tersebut juga ditampilkan keramahtamahan Sulaiman terhadap Ratu Saba'. Hal tersebut dibuktikan dengan simbol kebahasaan qi>la sebagai fiil mabni lilmajhul yang memiliki implikasi makna qubul al-'amal 'ala ma intawa 'alaihi al-qalb min ikhlas wa taqwa wa iman yang berarti menerimanya suatu aktivitas yang dilandaskan pada kerelaan hati, ketakwaan dan keimanan (Muhammad as-Sayyid Musa: via quranm.com). Ayat tersebut juga menggambarkan keberhasilan Ratu Saba' dalam melewati ujian Nabi Sulaiman. Ia mengetahui bahwa singgasana tersebut memilki kemiripan dengan singgasananya terdahulu. Pada ayat tersebut juga dijelaskan bahwa Ratu Saba' dan para kaumnya telah diberi tahu akan hal itu yang digambarkan dengan kalimat wa utina 'ilma min qabliha wa kunna muslimin.

Sebelum mencapai pengetahuan tersebut, peneliti yakin bahwa Ratu Saba' dalam komunikasi interpersonal dengan Nabi Sulaiman tidak hanya berhenti pada taraf sensing (pengamatan) yang terdapat pada ayat ke- 35. Namun sebenarnya taraf yang sudah dilalui Ratu Saba sama dengan taraf yang dilalui Nabi Sulaiman meskipun tidak diterangkan al-Quran secara intensif dan eksplisit. Ratu Saba' diyakini telah menafsirkan (interpreting) respon yang dilakukan Nabi Sulaiman karena ia menolak hadiah yang diberikan kepadanya dan gertakan yang ia lakukan. Berdasarkan penolakan yang dilakukan Sulaiman, Ratu Saba' yakin bahwa Sulaiman adalah nabi (Zaydan, 2009: 296). Adapun berdasarkan 'gertakan ancaman' dan 'repon tindakan' yang dilakukan Nabi Sulaiman menunjukkan bahwa beliau merupakan sinergi antara raja dan nabi. Interpretasi tersebut mendorong munculnya feeling (perasaan) kagum terhadap Nabi Sulaiman sehingga ia melakukan intending (tanggapan) dengan mendatanginya sebagaimana yang tertera pada ayat ke- 42 tersebut. Adapun pada ayat ke 43, al-Quran menjelaskan bahwa apa yang dilakukan Ratu Saba' (dan kaumnya) selama ini (menyembah matahari) menceganya untuk menyembah Allah.

6. Ungkapan (expressing) cinta Nabi Sulaiman dan Ratu Saba'

Allah berfirman:

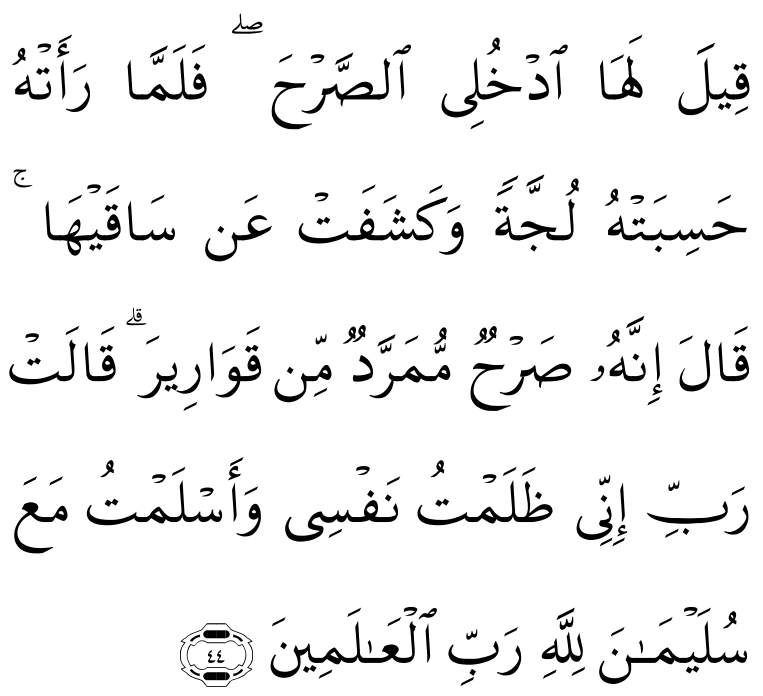

Ayat di atas menggambarkan dua bentuk ungkapan cinta yang disampaikan oleh Nabi Sulaiman dan Ratu Saba'. Pengungkapan (expressing) merupakan tahapan akhir dari proses pengungkapan perasaan. Ungkapan yang masih abstrak tersebut dibentuk oleh gaya bahasa yang digunakan al-Quran dalam menggambarkan perkataan Nabi Sulaiman kepada Ratu Saba'. Pada ranah simbol akan didapati keagungan gaya bahasa yang digunakan. Pada ayat tersebut al-Quran menggmbarkan keramahtamahan Nabi Sulaiman dengan menggunakan fiil mabni lilmajhul qi>la sebagaimana yang ada pada ayat sebelumnya. Adapun kata perintah 


\section{Jurnal al-Tsaqafa Volume 15, No. 02, Desember 2018}

udkhuli sharha menunjukkan bahwa Nabi Sulaiman ingin merasa dekat dengan Ratu Saba' (yas'uru bisyiddati qurbihi min malakati as-Saba'). (Basyuni 'Abdu al-Fattah: 190) Mengingat bahwa ketika seseorang merasa memiliki jarak hubungan yang jauh maka ia cenderung menggunakan harfu nida ya' yang disertai dengan nama orang yang diberi perintah seperti ya malakata asSaba'udkhuli as-sarha.

Ketika Ratu Saba' masuk ke istana tersebut, ia mengira bahwa lantai istana adalah air kolam yang besar lujjatun sehingga ia menarik kainnya hingga betisnya terlihat. Di dalam Lisan al-Arab lujjatun bermakna 'urdu dan mu'dzam (luas dan mayoritas/kapasitas yang besar) (Ibnu Manzur, tanpa tahun :354). Hal tersebut menunjukkan bahwa istana yang dimasuki oleh Ratu Saba sangatlah luas.

Melihat fenomena tersebut maka Nabi Sulaiman pun menjelaskan dan memperkenalkan istananya dengan ungkapan innahu sharhun mumarradun min qawarir yang kurang lebih bermakna istana yang memiliki sifat mumaradu yaitu mumalisun (licin) yang terbuat dari qawarir (kaca). Dari ranah imageri dapat dipahami bahwa istana yang dditunjukkan Nabi Sulaiman kepada Ratu Saba sangatlah megah, mewah dan anggun.

Berdasarkan apa yang telah diperlihatkan oleh Nabi Sulaiman kepadanya, Ratu Saba' menyadari bahwa selama ini ia mendzalami dirinya sendiri karena tidak menyembah Allah, tuhan yang disembah oleh Nabi Sulaiman dan membanggakan harta yang ia miliki. Ia pun menyerahkan diri kepada Sulaiman demi Tuhan bagi seluruh alam. Penyerahan diri tersebut digambarkan dengan menggunakan harfu jar ma'a. Sebagaimana yang disebutkan di muka bahwa penggunaan huruf $m a^{\prime} a$ berimplikasi pada pemaknaan pernikah yang terjadi antara keduanya sebagaimana yang diterangkan oleh as-Suyuti (2012: 268). Dengan demikian dapat disimpulkan bahwa Nabi Sulaiman telah mengungkapkapkan rasa cintanya kepada Ratu Saba' dan berhasil mengungkapkan cintanya kepada Tuhannya karena dapat menyeru manusia untuk menyembah-Nya. Mengingat bahwa hal tersebut merupakan tugas diakronis seorang rasul.

\section{KESIMPULAN}

Setelah melakukan analisis terhadap kisah Nabi Sulaiman dan Ratu Saba' di dalam Surat an-Naml dengan menggunakan teori semiotika Charles S. Peirce dan teori Komunikasi Interpersonal didapati bukti kuat dari segi kebahasaan bahwa keduanya melangsungkan pernikahan. Bukti yang dimaksud didasarkan pada simbol-simbol kebahasaan dan indeks yang merujuk pada lima tahapan penyampaian perasaan. Terlepas dari proyek diakronis setiap rasul untuk menyampaikan pesan Tuhannya, Nabi Sulaiman disinyalir juga memberikan indikasi-indikasi cinta kepada Ratu Saba, dan juga sebaliknya. Beberapa simbol kebahasaan yang merujuk pada indikasi cinta adalah penggunaan fi'il mabni li majhul qi>la guna memberikan kesan keramahtamahan Nabi Sulaiman terhadap Ratu Saba. Kata perintah langsung tanpa adanya harfu nida ya juga disinyalir menggambarkan keinginan Nabi Sulaiman untuk merasa dekat dengan Ratu Saba'. Adapun indikasi cinta yang ada pada diri Ratu Saba' telah nampak pada awal-awal episode kisah, di mana ia memeberikan respon positif terhadap surat yang dikirim oleh Nabi Sulaman. Adapun proses pengungkapan perasaan yang diterangkan al-Quran secara eksplisit pada diri Sulaiman adalah (1) pengamatan (sensing) 


\section{REPRESENTAMEN CINTA DALAM KISAH NABI SULAIMAN \\ DAN RATU SABA' SURAT AN-NAML \\ (Studi Analisis Semiotika dan Komunikasi Interpersonal)}

terhadap Ratu Saba', (2) menafsirkan (interpreting) respon Ratu Saba', (3) mengalami perasaan tertentu (feeling) yang diakibatkan penafsiran sebelumnya, (4) menanggapi (intending) perasaan tersebut, dan (5) mengungkapkan perasaan (expressing). Adapun proses pengungkapan perasaan yang diterangkan al-Quran secara eksplisit pada diri Ratu Saba' adalah (1) pengamatan (sensing) terhadap Nabi Sulaiman dan (2) pengungkapan (expressing) perasaan.

\section{DAFTAR PUSTAKA}

Aw, Suranto, Komunikasi Interpersonal, Yogyakarta: Graha Ilmu, 2011

Bankarad, Said, Simiyaiyyat wa atTa'wil, Madkhal lisimiyaiyyat Charles Sanders Peirce, Beirut: al-Markaz ats-Tsaqafi alArabiy, 2005

Danesi, Marcel, Pesan, Tanda, dan Makna, terj. Evi Setyarini dan Lusi Lian Piantiri, Yogyakarta: Jalasutra, 2012.

al-Fattah Fayudi, Basyuni Abd, Min Balaghoti an-Nudzum al-Qurani, Kairo: Muassasatu al-Mukhtar, 2010

Gulayain, Musthafa, Jami' ad-Durus alArabiyah, Beirut: al-Maktabah al-'Asriyah, 1993

Jalalain, Imam, Tafsir Jalalain, Beirut: Dar al-Kutub al-Ilmiah, 2012

Al-Jabiri, Muhammad 'Abid, Fahmu al-Qurani; at-Tafsir al-Wadih Hasba Tartibi anNuzul, Beirut: Markaz Dirasat al-Wihdah al'Arabiyah, 2008

Mandzur, Ibnu, Lisanu al-Arab, Beirut: Dar Sadir, Tahun tidak diketahui

Supraktiknya, A, Komunikasi Antarpribadi, Yogyakarta: PT Kanisius, 1995 Zaydan Abd al-Karim, al-Mustafad Min Qasas al-Quran, Beirut: Risalah, 2009
Zoest, Aart Van, Semiotika; Tentang Tanda, Cara Kerjanya, dan Apa Yang Kita Lakukan Dengannya, terj. Ani Soekowati, Jakarta: Yayasan Sumber Agung, 1993. 